Coloquio Interdisciplinario: «Memorias, saberes y redes de las culturas populares en América Latina, en tiempos del capitalismo global, In Memoriam

\title{
Carlos Monsivais»
}

\section{Graciela Maglia}

\section{Q OpenEdition \\ Journals}

\section{Edición electrónica}

URL: http://journals.openedition.org/bifea/4097

DOI: 10.4000/bifea.4097

ISSN: 2076-5827

\section{Editor}

Institut Français d'Études Andines

\section{Edición impresa}

Fecha de publicación: 1 agosto 2013

Paginación: 311-313

ISSN: 0303-7495

\section{Referencia electrónica}

Graciela Maglia, « Coloquio Interdisciplinario: «Memorias, saberes y redes de las culturas populares en América Latina, en tiempos del capitalismo global, In Memoriam Carlos Monsivais» », Bulletin de I'Institut français d'études andines [En línea], 42 (2) | 2013, Publicado el 08 agosto 2013, consultado el 06 noviembre 2020. URL : http://journals.openedition.org/bifea/4097 ; DOI : https://doi.org/10.4000/ bifea.4097

\section{(c) $(9)$}

Les contenus du Bulletin de l'Institut français d'études andines sont mis à disposition selon les termes de la licence Creative Commons Attribution - Pas d'Utilisation Commerciale - Pas de Modification 4.0 International. 
COLOQUIO INTERDISCIPLINARIO: «MEMORIAS, SABERES Y REDES DE LAS CULTURAS POPULARES EN AMÉRICA LATINA, EN TIEMPOS DEL CAPITALISMO GLOBAL, IN MEMORIAM CARLOS MONSIVAIS»

\section{Bogotá, 14-16 de mayo de 2013}

El Coloquio Interdisciplinario: Memorias, saberes y redes de las culturas populares en América Latina, en tiempos del capitalismo global, In Memoriam Carlos Monsiváis tuvo lugar en Bogotá (Colombia) entre el 14 y16 de mayo del año 2013. Fue organizado por la Pontificia Universidad Javeriana y la Universidad Externado de Colombia contando con el auspicio del Instituto Francés de Estudios Andinos (IFEA), la Oficina de Cooperación Regional de la Embajada de Francia en Perú y la Embajada de los Estados Unidos en Colombia.

Las conferencias centrales que siguieron a la Lección Inaugural de Jesús Martín Barbero, estuvieron a cargo de los siguientes especialistas nacionales e internacionales: Ana María Ochoa de la Universidad de Columbia (EE. UU.), George Yúdice de la Universidad de Miami (EE. UU.), Horacio Legrás de la Universidad de California Irvine (EE. UU.), Gérard Borrás del IFEA (Francia), Quince Duncan - Premio Nacional de Literatura- (Costa Rica), Yves Moñino del CNRS (Francia), Hugo Biagini del CONICET (Argentina), Fabián Sanabria, director del ICANH (Colombia), Armando Silva y Luis Alberto Suárez de la 
Universidad Externado de Colombia y Fred Rohner de la Pontificia Universidad Católica del Perú.

Por su parte, los paneles y ponencias ofrecieron un escenario polifónico para el debate en torno a las culturas populares frente a la globalización, los medios masivos, nuevas tecnologías, las subculturas, el cine comunitario, el arte callejero, las músicas locales, el grafitti y las iconografías y poéticas urbanas, las narrativas orales, literatura testimonial, el multiculturalismo, las culturas híbridas, las literaturas heterogéneas, las epistemes alternativas y las redes culturales.

A lo largo del coloquio se revisitó el debate en torno a la articulación problemática de las prácticas socioculturales, políticas y artísticas de las llamadas culturas populares en Latinoamérica, frente a los procesos globales de homogenización, masificación, transnacionalización y tecnocracia del capitalismo global. Asimismo, el encuentro reflexionó sobre las nuevas formas de inscripción y representación identitaria, como es el caso de las redes culturales transcontinentales y los complejos procesos de constitución de las culturas híbridas en América Latina. Se dialogó en torno a la crisis de las memorias y los saberes ancestrales de las oralidades primarias, frente a la nueva socialización discursiva planteada por la industria cultural y la comunicación massmediática en la era digital.

Las conferencias centrales, así como los páneles especiales y las ponencias temáticas giraron alrededor de los estudios culturales, los estudios subalternos, la literatura, la lingüística, la comunicación, la antropología, la industria cultural, el cine, la performance, el patrimonio, la música, la iconografía y la animación.

Repensar América Latina desde esta perspectiva permitió cuestionar desde varias disciplinas la consabida polarización entre alta cultura y cultura popular; dio un paso adelante en la des-exotización de «lo latinoamericano», desestabilizó la

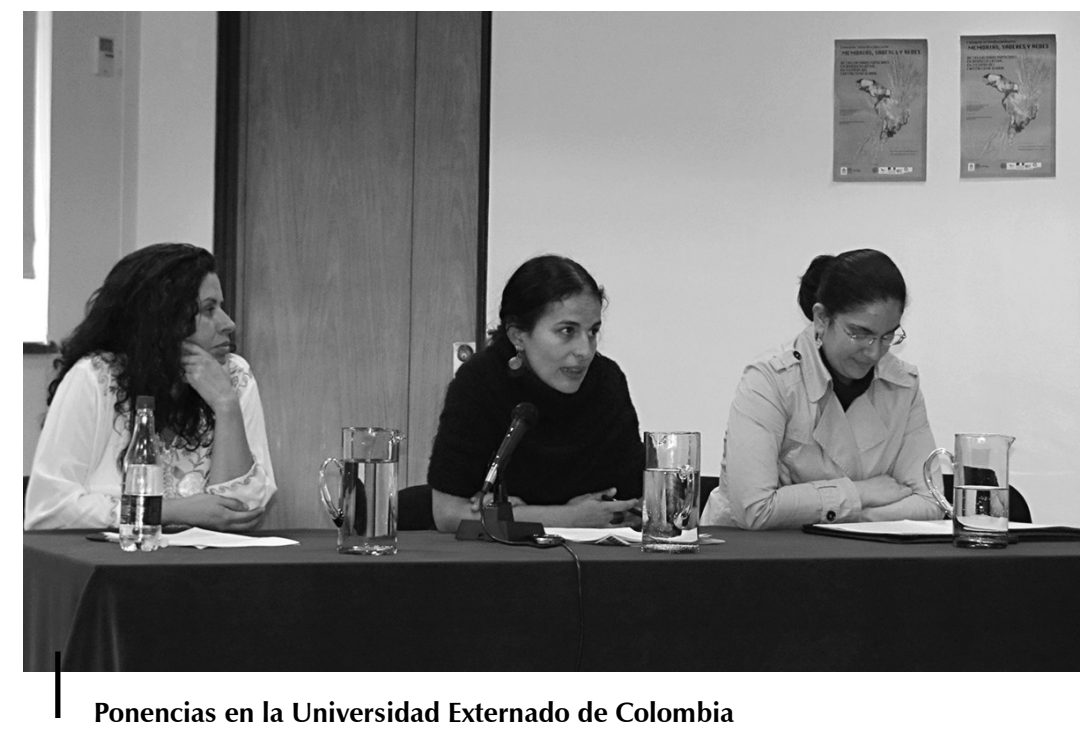




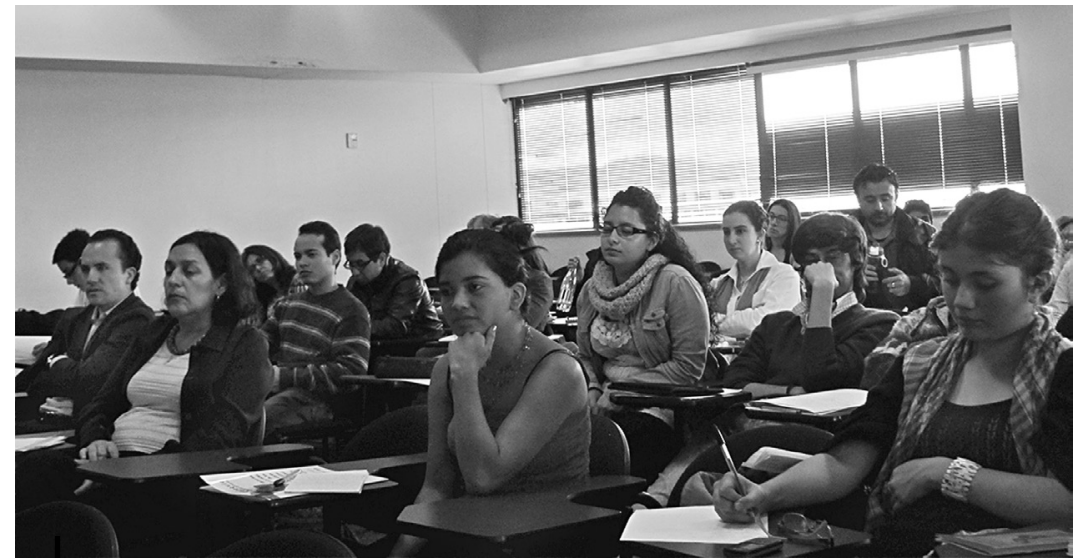

Público del coloquio Memorias, saberes y redes de las culturas populares en América Latina, en tiempos del capitalismo global

concepción racionalista de los «saberes», complejizó la noción de identidad, con la integración del discurso afro e indígena y puso en común proyectos y resultados de investigación que facilitaron el contrapunto transnacional y transcultural de nuestras experiencias.

\section{Graciela MAGLIA}

